\title{
15. CORRELATION OF REFLECTORS WITH LITHOLOGY FOR SITE 212
}

\author{
George Carpenter, Lamont-Doherty Geological Observatory, Columbia University, Palisades, New York
}

\section{INTRODUCTION}

Early cruises in the Indian Ocean revealed a series of short, linear crustal depressions (termed "deeps") in the southern Wharton Basin which appeared to be among the deepest features found in any world ocean basin. In later cruises of R.V. Vema and R.V. Conrad several more were discovered and in a few cases their trend and extent were established. Carpenter and Ewing (in press) described the features and suggested that they may be either disoriented fracture zones or grabens produced by crustal extension and thinning. Site 212 is of special interest as it was drilled in one of these features.

\section{REGIONAL SETTING}

The Wharton Basin is bound on the west by the Ninetyeast Ridge, on the south by Broken Ridge, and is divided by the Cocos Seamount chain which trends roughly east-west along latitude $12^{\circ} \mathrm{S}$. Site 212 was drilled in the deepest part of the Wharton Basin (south of the Cocos chain) in a water depth of 6243 meters (Figure 1). A detailed description of local physiography is not possible as a preliminary geophysical survey for this site was not made. However, some useful generalizations may be drawn from the rather sparse data. Total depth to acoustic basement of the small deep in which Site 212 was drilled is believed to be in excess of 7000 meters. The DSDP hole was drilled on the flank of the deep shown in Figure 2.

\section{SEDIMENT DISTRIBUTION}

Figure 3 is a sediment isopach map of the area in the immediate vicinity of Site 212 . The greatest thicknesses are observed to be concentrated ("ponded") in depressions in the crust. The flat-lying, acoustically reflective sediments observed in these ponds are thought to be largely calcareous turbidites derived from local sources above the calcium carbonate compensation level. Very little terrigenous sediment was found in Site 212. The most obvious sources for these redeposited sediments are the Ninetyeast Ridge to the west, Broken Ridge to the south, or the Wallaby Plateau region to the east. All of these elevations are capped with pelagic carbonates up to 800 meters thick (Ewing et al., 1969). However, present-day turbidite deposition appears to be negligible as piston cores throughout the southern Wharton Basin show mostly brown clays to a depth of at least 10 meters. The southern Wharton Basin is also isolated from the influx of terrigenous materials (especially Bengal Fan sediments) by the Cocos Seamount chain and the Ninetyeast Ridge.

Sediments contained in the deep in which Site 212 was drilled are acoustically well stratified to $\approx 0.6 \mathrm{sec}$ of two-way travel time (Figure 2) beneath which the reflectors become blurred and indistinct. No clear basement reflection

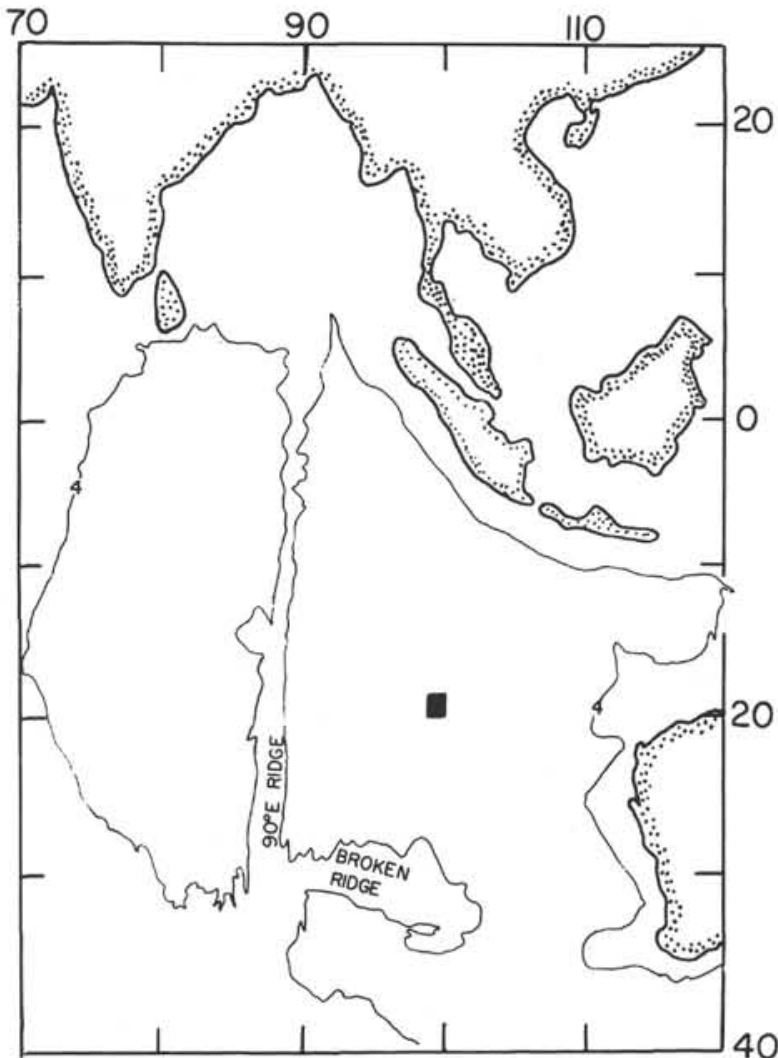

Figure 1. General location map for Site 212. Blackened area is shown in Figures 3 and 4.

from the floor of the deep was recorded, indicating depth to acoustic basement may be greater than is shown in Figure 3. The reflectors show evidence of distortion commencing just below the second strong reflector (about $0.04 \mathrm{sec}$ subbottom). This distortion is probably due to some second-order postdepositional effect, such as differential compaction, rather than tectonism. It is probable that differential compaction also accounts for the slight onlap of reflectors on the walls of the deep.

\section{TOPOGRAPHY}

Figure 4 shows the bathymetry in the vicinity of the site contoured in 200-meter intervals from corrected soundings (Matthews, 1939). The north-south trending deep in which Site 212 was drilled is outlined by the $6.2-\mathrm{km}$ contour. Unfortunately, it is not yet possible to establish the northern limit of the deep. The deep does not show a great deal of topographic relief as it has been filled with sediments (largely calcareous turbidites) to nearly the level of the average regional depth of the basin. 


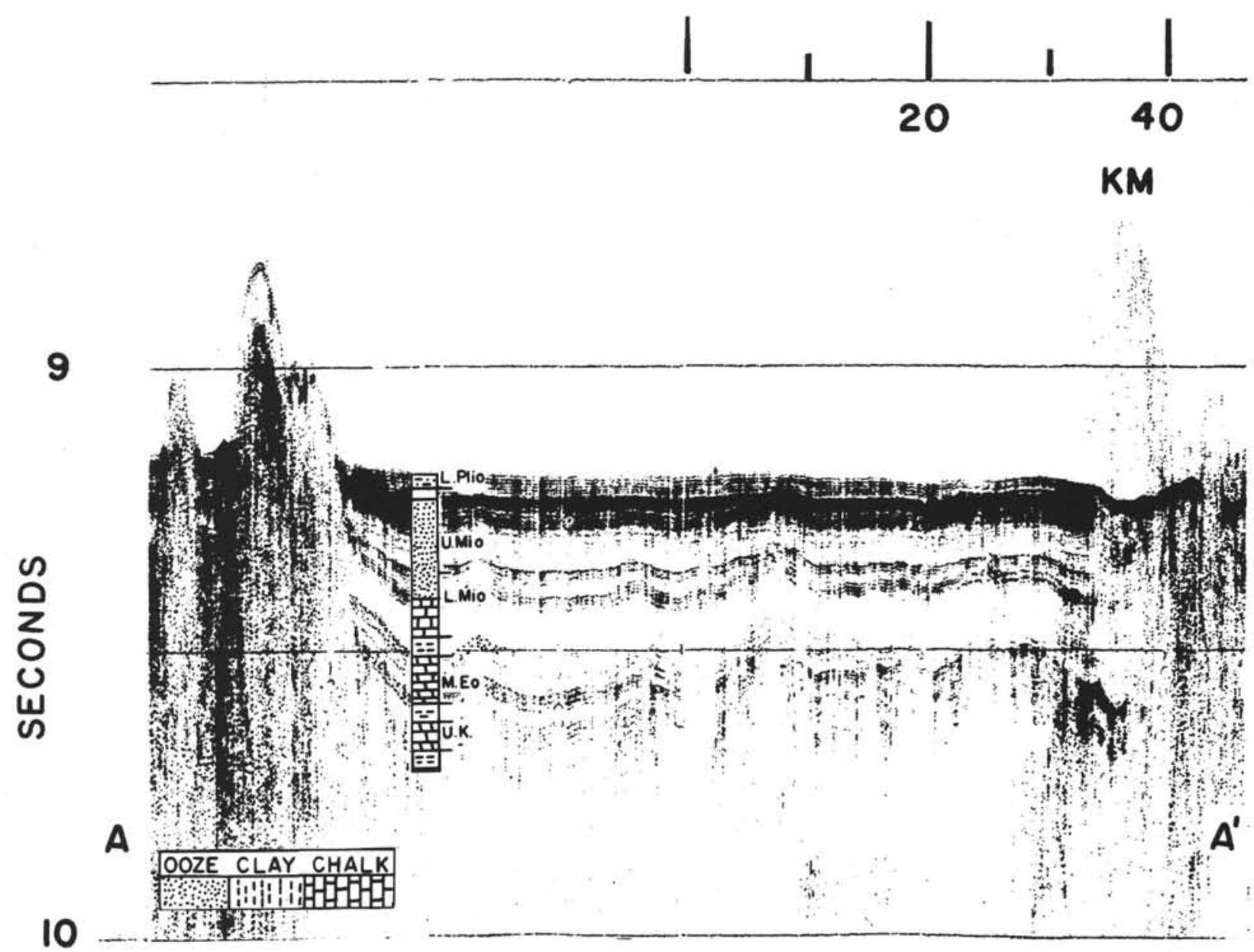

Figure 2. Seismic reflection profile over Site 212 with a lithologic diagram (corrected for velocity) superimposed. Left-hand edge of the diagram marks the position of the hole. Vertical scale in seconds of two-way travel time. Track shown in Figure 3. Vertical exaggeration $\approx 50: 1$.

\section{CORRELATION OF REFLECTORS WITH LITHOLOGY}

Because Site 212 was drilled quite near the flank of the deep, it was necessary to locate the lithologic diagram in Figure 2 so that the left edge of the section marks the position of the hole. This is about the point where the reflectors begin to lap onto the west wall of the deep. The correlations are largely based on sedimentary velocities determined from the cores since no complementary seismic refraction or downhole acoustic logging data are available for this site. The velocities were taken with a Hamilton frame velocimeter (see Table 1) and are considered sufficiently accurate for correlation purposes. However, in general, velocities determined with the Hamilton frame velocimeter will usually be lower than in situ velocities because of higher temperature and lower pressure prevailing at the surface, drilling disturbance of the sample, or any other factor which tends to reduce the density of the recovered sample from the in situ value. The velocities were averaged over given lithologic units as determined from the DSDP cores after the method of McManus et al. (1970).
It can be seen from Figure 2 that the base of the nannofossil ooze unit corresponds to the abrupt cessation of reflections occurring at about $0.24 \mathrm{sec}$ subbottom. The many internal reflectors in the ooze unit seem to correspond to very subtle physical changes. The few GRAPE determinations made on the Site 212 section generally support this view. Average interval velocity for this lithologic unit is about $1850 \mathrm{~m} / \mathrm{sec}$. The second conspicuous set of reflectors corresponds to a moderately indurated nannofossil chalk of middle Eocene age. Average interval velocity for this unit is about $1950 \mathrm{~m} / \mathrm{sec}$. Below the Eocene chalk unit reflectors become vaguely defined and no correlations are possible.

In general, correlation of reflectors with lithology for Site 212 is possible only in a rather broad sense. Certain lithologic units, particularly calcareous turbidites, are characterized by a high degree of acoustic stratification, while clays tend to be relatively unreflective. The acoustic stratigraphy for Site 212 shows a general pattern of highly reflective turbidites interspersed with acoustically unreflective clay units. 


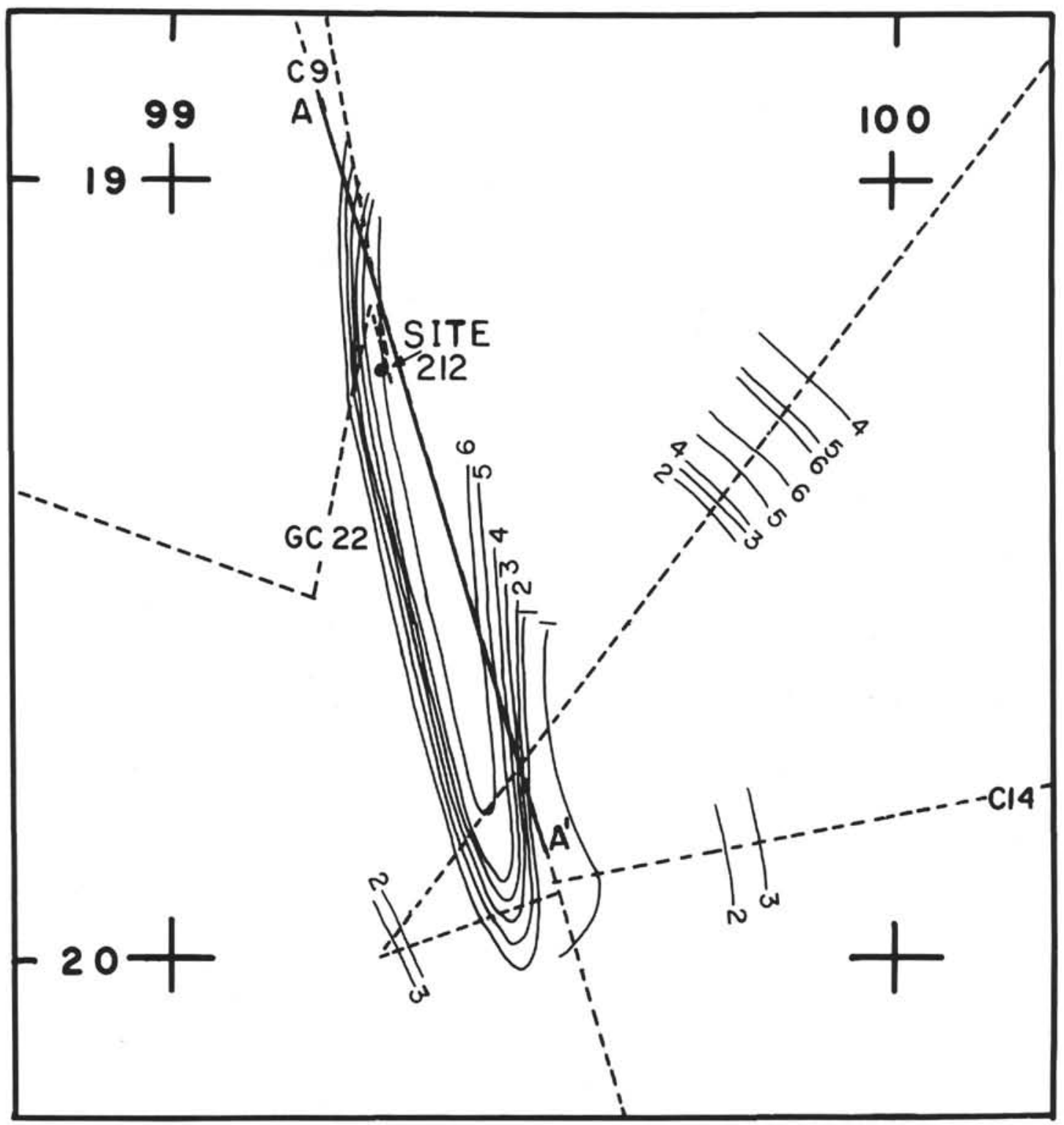

Figure 3. Isopach map of sediments in the vicinity of Site 212 contoured to the deepest observed reflector. Dotted lines are ship's track. Profile A-A' shown in Figure 2 is indicated as a heavy solid line. Contours in tenths of seconds of two-way travel time (nominal 100 meters).

\section{REFERENCES}

Carpenter, G. and Ewing, J., in press. Crustal deformation in the Wharton Basin: J. Geophys. Res.

Ewing, M., Eittreim, S., Truchan, M., and Ewing, J., 1969. Sediment distribution in the Indian Ocean, Deep-Sea Res., v. 16, p. 231-248.
Matthews, D. J., 1939. Tables of the velocity of sound in pure water and sea water for use in echo sounding and sound ranging: London (Admiralty Office).

McManus, D. A. et al., 1970. Initial Reports of the Deep Sea Drilling Project, Volume V: Washington (U.S. Government Printing Office), p. 545-548. 


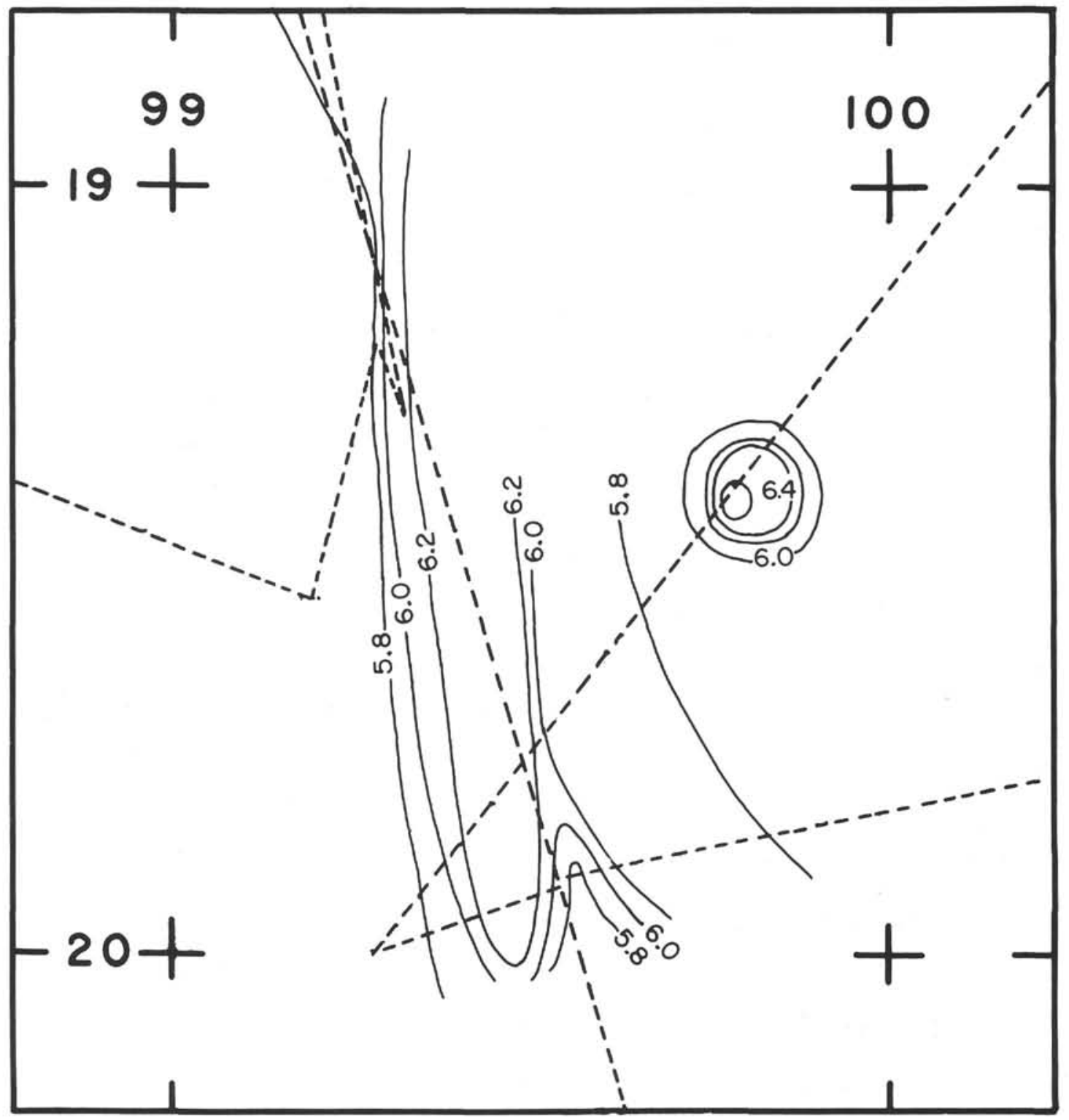

Figure 4. Bathymetry or the area near Site 212 contoured in 200-meter intervals. Soundings corrected after Matthews (1939). 
TABLE 1

Deep Sea Drilling Project

Hamilton Frame Sonic Velocities for Site 212

\begin{tabular}{|c|c|c|c|}
\hline Core & Section & $\begin{array}{l}\text { Depth in Hole } \\
\text { (m) }\end{array}$ & $\begin{array}{l}\text { Velocity } \\
(\mathrm{m} / \mathrm{sec})\end{array}$ \\
\hline 2 & 4 & 14.42 & 1474 \\
\hline 2 & 4 & 14.42 & 1467 \\
\hline 9 & 1 & 137.35 & 1532 \\
\hline 9 & 1 & 136.52 & 1557 \\
\hline 18 & 1 & 317.55 & 1593 \\
\hline 18 & 3 & 320.73 & 1704 \\
\hline 19 & 1 & 327.37 & 1895 \\
\hline 19 & 1 & 327.37 & 1689 \\
\hline 21 & 1 & 345.20 & 1806 \\
\hline 21 & 1 & 345.20 & 1883 \\
\hline $23^{\mathrm{a}}$ & 5 & 370.70 & 2827 \\
\hline 23 & 5 & 370.01 & 1971 \\
\hline 23 & 5 & 370.01 & 1989 \\
\hline 26 & 5 & 399.63 & 1892 \\
\hline 26 & 5 & 399.63 & 1910 \\
\hline 26 & 5 & 398.65 & 1977 \\
\hline 26 & 5 & 398.65 & 1993 \\
\hline 28 & 1 & 412.87 & 1623 \\
\hline 28 & 1 & 412.87 & 1581 \\
\hline 28 & 1 & 411.58 & 1681 \\
\hline 28 & 1 & 411.58 & 1591 \\
\hline 31 & 4 & 445.87 & 2039 \\
\hline 31 & 4 & 444.87 & 2112 \\
\hline 32 & 3 & 453.53 & 1660 \\
\hline 32 & 3 & 453.00 & 2074 \\
\hline 38 & 2 & 508.80 & 1634 \\
\hline $39^{b}$ & 1 & 517.10 & 4370 \\
\hline $39^{b}$ & 2 & 517.92 & 4836 \\
\hline
\end{tabular}

${ }^{\text {a}}$ High velocity stringer.

basalt. 